В период существования стоянки «Байбек» (период неолита) береговая зона Каспийского моря, в соответствии со второй стадией новокаспийской трансгрессии, находилась в непосредственной близости от стоянки. Неолитическая стоянка могла находиться практически в береговой зоне. Это подтверждается явно выраженной окраской фото-тона на фрагменте космического снимка, сделанного в тепловом инфракрасном спектральном диапазоне (см. рисунок 2), который создает примерную картину уреза стояния вод Каспийского моря в тот период.
Это подтверждается также общей картиной абсолютных отметок окружающего стоянку ландшафта, которая показывает, что поднятие вод Каспия даже до отметки -22 м переводит территорию стоянки в прибрежную зону [1].

\section{СПИСОК ЛИТЕРАТУРЫ}

1. Отчет по тематическому дешифрированию. «Специфика контекста расположения стоянки каменного века «Байбек» Красноярского района Астраханской области по данным «Landsat-8» и «ЕО-1»». ГНПРКЦ «ЦСКБ - Прогресс», Самара, 2014, 61c.

\title{
(C) 2014
}

\section{THE QUESTION OF CONTEXT SPECIFIC LOCATION STONE AGE "BAIBEK"}

\section{N.P. Antimonov, lead engineer-designer}

Federal state unitary enterprise State research-andproduction space centre "CSKB-PROGRESS", Samara (Russia)

Annotation: Practice of buried objects detection on satellite images obtained from spacecraft "Landsat- 8 " is considered. Keywords: Remote sensing; searching of buried objects; archaeology.

\section{УДК 902.6}

О СООТНОШЕНИИ ПАМЯТНИКОВ КАИРШАКСКОГО И ТЕНТЕКСОРСКОГО ТИПОВ (C) 2014

\author{
A.B. Барацков, аспирант кафедры отечественной истории и археологии \\ Поволжсккая государственная сочиально-гуманитарная академия, Самара (Россия)
}

Аннотащия: На основании новых данных и тщательной проработке исследованного материала автор аргументирует тезис, что памятники каиршакского и тентексорского типов являются последовательными этапами одной культуры, подтверждая предположение А.А. Выборнова.

Ключевые слова. Нижнее Поволжье; Северный Прикаспий; неолит; каиршакско-тентексорская культура; археологическая керамика; кремневая индустрия.

До сих пор среди ученых нет единого мнения о том, являются ли памятники каиршакского и тентексорского типов последовательными этапами одной культуры или они представляют собой разные культурные образования.

По всей вероятности, аридизация климата, случившаяся в интервале 7500-7200 л.н. [1; 2], стала причиной миграции части каиршакского населения на север. Количество неолитических памятников по сравнению с предыдущим и последующим интервалами сокращается, культурные слои редки и маломощны, а количество находок незначительно, следовательно, население покидало как крупные стоянки, так и менее заселенные. По мнению В.В. Ставицкого, это придало определенный импульс развитию памятников типа Варфоломеевки и Джангара и привело к распространению прочерченнонакольчатой традиции украшения керамики. В дальнейшем происходит ее эволюция: уменьшается удельный вес прочерченного орнамента, который сокращается до $11 \%$ на сосудах верхнего слоя Варфоломеевской стоянки и сходит на нет на поселении Тентексор. Кроме возрастания роли накольчатого орнамента, на варфоломеевской керамике наблюдается появление ряда сложных узоров, которые отсутствуют на Каиршаке III, но являются характерными для Тентексора. Это состоящие из наколов прямоугольники, фигуры, напоминающие песочные часы, горизонтальные зигзаги, шевроны, вписанные друг в друга ромбы [3, с. 206]. В верхнем слое Варфоломеевки уменьшается количество сосудов с наплывом на венчике, которые на Тентексоре представлены единичными экземплярами (4,5\%). Примерно равную долю в посуде этих комплексов занимают профилированные сосуды $(24 \%$ и $20 \%)$. По пути сближения с тентексорской развивается и каменная индустрия Варфоломеевской и Джангарской стоянок. На основании этих выводов В.В. Ставицкий считает, что джангарско-варфоломеевские древности не только заполняют хронологический пробел между памятниками каиршакского и тентексорского типов, но и иллюстрируют процесс трансформации одних традиций в другие.

Исследователи отмечают значительный хронологический разрыв между развитым каиршакским и поздним тентексорским этапами местного неолита $[4 ; 5 ; 6 ; 7]$. Тем не менее на территории Северного Прикаспия были обнаружены небольшие, но очень интересные комплексы, которые могли бы претендовать на более раннюю хронологическую позицию, чем материалы стоянок Тентексор и Жеколган. Одним из таких памятников является стоянка Качкарстау [8, с. 87]. Культурный слой памятника полностью разрушен эоловой эрозией. Однако обнаруженные на поверхности артефакты располагались на ограниченной площади, и какой-либо планиграфической локализации кремневых изделий от фрагментов керамики не прослеживалось $[8$, с. 88$]$.

Керамика стоянки изготавливалась из илистого сырья с примесью ракушки. Орнамент наносился крупными наколами подпрямоугольной или овальной формы в отступающей манере, резными линиями, аморфными ямочными вдавлениями. Несмотря на ограниченность коллекции (17 фрагментов), можно сделать ряд замечаний.

Для тентексорской посуды характерна обильная примесь раковины. Насечки и пальцевые вдавления по срезам, а также наличие наплывов у венчиков сближает фрагменты Качкарстау с поздненеолитическими. Крупные наколы в отступающей манере характерны именно для тентексорских комплексов. Таким образом, керамический набор стоянки Качкарстау сближается с поздненеолитическими. Однако кремневый инвентарь этой стоянки архаичнее, чем тентексорский. Сырье неоднородно, преобладающим является: непрозрачный белесый халцедон и полупрозрачный халцедон различных оттенков от серого до синеватого [8, с. 89]. Такое сырье характерно для памятников развитого неолита - стоянок Каиршак I - IV [9, с. 106]. Характер заготовок для изготовления орудий позволяет сделать следующие выводы.

По наличию крупных пластинчатых сколов данная коллекция сближается с материалами тентексорского типа. Прием получения крупных пластин ударом еще не сформировался окончательно, что еще раз указывает на более архаичную технологию, чем тентексорская. Самарский научный вестник. 2014. № 3(8) 
Наличие стандартных пластин меньших параметров наводят на аналогии с материалами каиршакского типа. Однако на стоянках этого периода отсутствует прием получения пластин ударом, столь характерный для материалов памятника Качкарстау. Таким образом, технология изготовления орудий на стоянке Качкарстау носит промежуточный характер [8, с. 92]. С одной стороны, наличие в данной коллекции техники резцового скола отличает ее от тентексорской, с другой - сближает с каиршакской, особенно выраженной в материалах стоянки Каиршак I [9, с. 97]. Техника ретуширования продольных граней скребков в подавляющем большинстве присуща тентексорской традиции и в меньшей степени проявляется среди орудий каиршакского типа. Таким образом, и по данным показателям материалы стоянки Качкарстау проявляют переходные черты между каиршакскими и тентексорскими памятниками [8, с. 93].

Присутствие в коллекции стоянки Качкарстау обломков геометрических микролитов: трапеции со струганной спинкой, аналогичной тентексорским, а также сегмента и высокой трапеции, типичной для каиршакских материалов - также подтверждают связующий характер этого памятника. Такое же сочетание микролитов - сегменты и трапеции со струганной спинкой - отмечены А.И. Юдиным в слое 2Б Варфоломеевской стоянки, материалы которого более ранние, чем тентексорские [4].

Иначе говоря, описанная коллекция может свидетельствовать о существовании на данной территории памятников более ранних, чем Тентексор и Жекалган. Датировки, полученные в Киевской радиоуглеродной лаборатории под руководством Н.Н. Ковалюха, подтверждают данное пред-

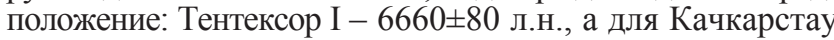
$-6730 \pm 80$ л.н. [10].

На джангарской и варфоломеевской посуде специфические каиршакские композиции, состоящие из прочерченных линий в обрамлении наколов, встречаются не часто. Подобная керамика фиксируется в нижних слоях данных поселений, которые их исследователи синхронизируют с существованием Каиршака III. Между тем подобная синхронизация в значительной мере базировалась на радиоуглеродной дате из нижнего слоя Варфоломеевской стоянки и сходном составе споро-пыльцевого комплекса этого слоя с каиршакским [11]. Это сравнение вызывает сомнения у ряда специалистов [3]. Памятники находятся в различных климатических зонах, Варфоломеевская стоянка находится севернее, климат там не такой засушливый, и растительный состав значительно отличается. А радиоуглеродные определения нижнего слоя Варфоломеевской стоянки $(7250 \pm 80)$ отличается от каиршакских $(7775 \pm 42)$ примерно на 500 лет. Нижний слой поселения Джангар $(6990 \pm 90)$, судя по радиоуглеродным датировкам, моложе Каиршака III более чем на 700 лет. Варфоломеевка и Джангар по радиоуглеродным определениям ближе к стоянке Каиршак I (7230 $\pm 90 ; 7100 \pm 200)$.

Несмотря на констатацию значительных отличий между памятниками каиршакского и тентексорского типов, объясняющихся значительным хронологическим разрывом, Е.В. Козин обосновывает генетическую преемственность каиршакских и тентексорских стоянок в рамках сероглазовской культуры, где ранний неолит представлен памятниками типа Кугат IV и Кулагайси, средний неолит - каиршакскими памятниками и поздний - тентексорскими [4, с. 64-65]. Хронологические разрывы между культурными типами памятников, по мнению Е.В. Козина, были вызваны периодически резким ухудшением природно-климатических условий, которые вынуждали население перемещаться на окраины Прикаспийской низменности [4]. Привлекая данные И.Н. Васильевой, Е.В. Козин приходит к выводу о родственности и преемственности технологических традиций изготовления керамики на всем протяжении развития неолита. Кроме того, выявляется преемственность и в развитии орнаментальной традиции, что отражает культурное единство населения [12].

Предположения Е.В. Козина о преемственности каиршакских и тентексорских комплексов в рамках сероглазовской культуры находит поддержку в сероглазовских комплексах. В них обнаружены сосуды и с типичным каиршакским орнаментом, нанесенные в прочерчено-накольчатой технике (рис. 1. 10) Ю, и сосуд, украшенный геометрическим орнаментом, выполненный мелким наколом (рис. 1. 11), характерным для тентексорской посуды. Примечательно, что на стоянке Каиршак III встречается орнамент, идентичный сероглазовскому (рис. 1. 5,6). И точно такой же орнамент мы видим на неолитической стоянке Байбек в Северном Прикаспии (рис. 1. 9). Стоянка Байбек относится к каиршакскому типу, но есть связь и с тентексорским типом [13]. Орнаментальные композиции двух памятником имеют ряд схожих композиций, отличаются они лишь способом нанесения. Для стоянки Байбек в радиоуглеродной лаборатории г. Познань была получена дата по нагару с керамики - 7350 \pm 50 л.н. [14]. Эта дата соответствует периоду сильной аридизации, проходившей в то время в Северном Прикаспии [1], но, по-видимому, население не покинуло стоянку, благодаря близости Каспийского моря. Таким образом, стоянка Байбек заполняет хронологический разрыв между памятниками каиршакского и тентексорского типов.

П.М. Кольцов объясняет различия между каиршакскими и тентексорскими типами памятников не только значительным хронологическим, а следовательно, и культурным разрывом [5, с. 69], но и различием в кремневом инвентаре. П.М. Кольцов отмечает, что для каиршакских памятников характерна пластинчатая техника с высокой степенью микролитоидности. В отличие от них, тентексорские стоянки демонстрируют упадок микролитоидной техники. Существенные различия наблюдаются и в керамике, например, в орнаменте, который является достаточно консервативным элементом В материальной культуре древних племен [6, с. 130]. В результате сильной аридизации население, создавшее памятники каиршакского типа, вынуждено смещаться к северу, в более благоприятные места обитания. На заключительной стадии неолита в регионе появляются памятники тентексорского типа, имеющие несколько иную культурную традицию [7, с. 294]. Сказанное выше не позволяет считать стоянки типа Каиршак и Тентексор двумя хронологическими ступенями в развитии одной археологической культуры. На классификационном уровне анализа неолитический материал стоянки Каиршак является отражением одной археологической культуры, а материал стоянки Тентексор - другой. Такие памятники, как Тентексор I, относятся к «пережиточному» неолиту, или «постнеолиту», и являются, прежде всего, категорией археологической [6, с. 131; 7 с. 294]. Однако радиоуглеродные определения верхнего слоя поселения Джангар (6564 44 ) синхронны стоянке Тентексор $-6650 \pm 100$ и $6540 \pm 100$ [15]. Они позволяют увидеть, что одновременные памятники могут развиваться поразному.

Типологические и хронологические различия каиршакских и тентексорских типов отметили их первооткрыватели [16, с. 43-45], но в рамках одной культуры. А.А. Выборнов считает, что хронологическое несоответствие памятников каиршакского и тентексорского типов, действительно, имеет реальные основания. Однако разрыв не столь уж велик, и, как мы видим, он заполняется памятниками переходного характера. На примере неолитической стоянки Байбек мы можем видеть, что не все население Каиршака III уходит на север, спасаясь от аридизации, начавшейся, по данным специалистов [1; 2, с. 52], с 7500 л.н. Часть населения адаптируется к засушливым условиям и отходит ближе к р. Кигач и Каспийскому морю. Помимо охоты, древние люди осваивали и рыбный промысел, о чем свиде- 
тельствуют позвонки рыб, найденные в анатомической последовательности в слое памятника.

Что касается хронологического разрыва, то прослеживается определённая хронологическая неоднородность памятников внутри тентексорской группы. Судя по характеру кремневого инвентаря стоянки Качкарстау, а также по радиоуглеродным датировкам, можно с уверенностью констатировать более архаичный облик этого памятника по сравнению с Жеколганом I и Тентексором. Стоянка Тентексор III также является более древним памятником, что подтверждается архаичной керамикой и радиоуглеродной датой $-7005 \pm 90$ л.н. [17]. Стоит отметить еще один момент, сближающий памятники каиршакского и тентексорского типа. Во втором штыке жилища стоянки Каиршак III найдены три фрагмента от одного сосуда тентексорского типа (рис. 1. 7,8). Они отличаются от каиршакских и сходны с тентексорскими. Но в отличие от последних, представленных на собственно стоянке Тентексор и более раннем комплексе этого типа стоянке Качкарстау, они тоньше и прочнее последних. Овальные наколы в отступающей манере более мелкие и нанесены поверхностно, а не так глубоко, как на тентексорской посуде. Можно предположить, что эти фрагменты, как и подлощенные кости лучшей сохранности из соседнего квадра-

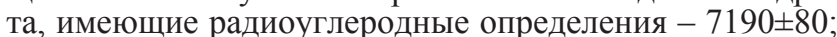
$7010 \pm 80$ и 7030 100 л.н., принадлежат более позднему, чем основной каиршакский комплекс - раннему тентексорскому типу [19, с. 201]. Они выглядят более ранними, чем фрагменты стоянки Тентексор III, которые датируются $-7005 \pm 90$ л.н. Видимо, они появились на памятнике уже после того, как каиршакское население покинуло его, и относятся не к материалам каиршакского типа, а к раннему тентексорскому типу.

Еще одним важным подтверждением единства каиршакско-тентексорской культуры могут выступать четыре фрагмента керамики, найденные в третьем горизонте стоянки Каиршак III. Орнаментальные композиции на фрагментах керамики идентичны, но на двух фрагментах орнамент нанесен в прочерчено-накольчатой технике (рис. 1. 3,4), а еще два фрагмента украшены наколами (рис. 1. 1,2). Вероятнее всего, фрагменты, украшенные наколом, попали на стоянку уже после того, как каиршакское население покинуло ее, и принадлежат к материалам раннего тентексорского типа.

А.А. Выборнов отмечает, что в кремневом инвентаре памятников Каиршак и Тентексор отмечается яркая отличительная черта - смена форм геометрических микролитов от сегментов в каиршакских к трапециям в тентексорских материалах. Однако можно привести ряд примеров из культур сопредельных территорий, где прослеживается данный процесс. В кельтеминарской культуре «рогатые» трапеции сменяются на высокие треугольники [20, с. 64-89]. В керамическом инвентаре главной отличительной чертой является доминирование прочерченной техники нанесения орнамента в каиршакских комплексах, а в тентексорских - накольчатой. Но существует ряд случаев хронологического изменения техники нанесения орнамента. В верхневолжской культуре на раннем этапе доминирует тычково-прочерченная техника орнаментации, а на позднем ее этапе - гребенчатая. Схожая ситуация прослеживается и в кельтеминарской культуре. Как уже упоминалось выше, орнаментальные композиции на памятнике Каиршак III находят множество аналогий с Тентексором, различает их лишь способ нанесения. Следовательно, Варфоломеевская стоянка может стать еще одним примером, так как здесь тоже прослеживается изменение способов нанесения орнамента от нижних слоев $33 \%$ сосудов с прочерками) до верхних горизонтов (12\% сосудов с прочерками) при увеличении техники накола $[11$, с. 4-5]. Исходя из вышесказанного, мы приходим к выводу о том, что смена способов нанесения орнамента с прочерчено-накольчатого на посуде каиршакского Самарский научный вестник. 2014. № 3(8) типа и накольчатого на тентексорском типе не может являться веским аргументом для выделения их в отдельные археологические культуры.

А.А. Выборнов считает, что тентексорский тип возникает на каиршакской основе и на каком-то втором культурном компоненте. Этот компонент не джангарский, так как к моменту появления тентексорцев джангарцы уже модифицируются в варфоломеевский тип. Однако и с ним у тентексорцев сходство носит весьма условный характер, что не позволяет присоединиться к точке зрения исследователей о возвратном характере происхождения тентексорских особенностей. Если вышеперечисленные традиции шли эволюционным путем, то тентексорские древности вторым компонентом, возможно, имеют неместную основу [17].

Таким образом, до получения новых данных более обоснованным представляется тезис А.А. Выборнова о каиршакских и тентексорских комплексах как этапах в развитии одной культуры, характеризующей неолит левобережья степного Поволжья.

\section{СПИСОК ЛИТЕРАТУРЫ}

1. Иванов И.В. Изменение климатических условий степной зоны в голоцене // Проблемы эпохи неолита степной и лесостепной зоны Восточной Европы. Оренбург: Оренбургский гос.пед.ин-т, 1986. С. 20-22.

2. Лаврушин Ю.А., Спиридонова Е.А., Сулержицкий Л.Д. Геолого-палеологические события севера аридной зоны в последние 10 тыс. лет // Проблемы древней истории Северного Прикаспия. Самара: Самарский гос.пед. ун-т, 1998. С. 40-65.

3. Ставицкий В.В. Дискуссионные вопросы изучения Нижневолжского неолита // Историко-археологические изыскания. Вып. 6. Самара: Самарский гос.пед.ун-т, 2004. C. $205-218$

4. Козин Е.В. О культурном своеобразии памятников эпохи неолита Северного Прикаспия // Проблемы древней истории Северного Прикаспия. Куйбышев: Куйбышевский гос.пед.ин-т, 1990. С. 24-25.

5. Кольцов П.М. О культурной принадлежности неолитических памятников Северного Прикаспия // Вопросы археологи юга Восточной Европы. Элиста: Калмыцкий гос.ун-т, 1990. С. 62-71.

6. Кольцов П.М. Поселение Джангар // Человек и его культура в неолите Северо-Западного Прикаспия. М.: Новый хронограф, 2004. 156 с.

7. Кольцов П.М. Мезолит и неолит Северо-Западного Прикаспия. М.: Воскресенье, 2005. 352 с

8. Выборнов А.А., Горащук И.В. Стоянка Качкарстау в Северном Прикаспии // Вестник Прикаспия. №1. Пенза, 2008. С.76-87.

9. Выборнов А.А., Козин Е.В. Неолитическая стоянка Каиршак I в Северном Прикаспии // Археологические культуры Северного Прикаспия. Куйбышев: Куйбыш. гос.пед.ин-т, 1988. С. 92-105.

10. Выборнов А.А. Корректировка радиоуглеродной хронологии неолита Нижнего Поволжья // Известия Самарского научного центра РАН. Т.10, №4. Самара: СНЦ РАН. 2008. С.1240 -1255.

11. Юдин А.И. Неолит и энеолит степного Заволжья //Автореф. дисс. ... канд. ист. наук. М., 1995. 16 с.

12. Козин Е.В. Неолит Северного Прикаспия// Автореф. дисс....канд. ист. наук. Ижевск, 2002. 27 с.

13. Гречкина Т.Ю., Кутуков Д.В. Неолитическая стоянка Байбек // Народы Прикаспийского региона. Элиста, 2009. С.20-23.

14. Выборнов А.А., Андреев К.М., Барацков А.В., Гречкина Т.Ю., Лычагина Е.Л., Наумов А.Г., Зайцева Г.И., Кулькова М.А., Гослар Т., Ойнонен М., Посснерт Г. Новые радиоуглеродные данные для материалов неолита - энеолита Волго-Камья // Известия Самарского научного центра РАН. Т.16, №3, Самара: СНЦ РАН. 2014. С.242-248.

15. Выборнов А.А., Андреев К.М., Барацков А.В., Кулькова М.А., Кольцов П.М., Юдин А.И., Джалл Т., 
Гослар Т., Ойнонен М., Посснерт Г., Филлипсен Б.Новые данные по радиоуглеродной хронологии неолита лесостепного и степного Поволжья // Известия Самарского научного центра РАН. Т.15, №5, Самара: СНЦ РАН, 2013. С.254-260.

16. Васильев И.Б., Выборнов А.А. Неолит Поволжья. Куйбышев: КГПИ, 1988. 112 с.

17. Выборнов А.А. Неолит степного - лесостепного Поволжья и Прикамья// Автореф. дисс. ... докт. ист. наук. Ижевск, 2009. С.44.
18. Барацков А.В., Выборнов А.А., Кулькова М.А. Проблемы абсолютной хронологии неолита Северного Прикаспия // Известия Самарского научного центра РАН. Том 14, № 3. Самара: Изд-во СНЦ РАН, 2012. С. 200-204. 19. Барацков А.В. Планиграфический и стратиграфический анализ распределения керамики стоянки Каиршак III // Археология восточно-европейской степи. Выпуск

10. Саратов: Саратовский гос.ун-т, 2013. С.58-65.

20. Виноградов А.В. Древние охотники и рыболовы Среднеазиатского междуречья. М.: Наука, 1981. 173 с.

\section{ИЛЛЮСТРАЦИИ}

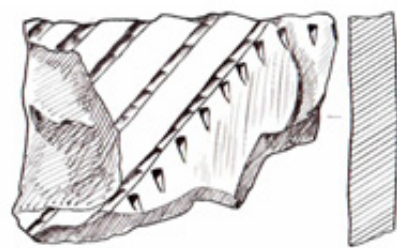

1

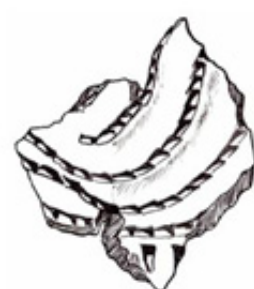

2

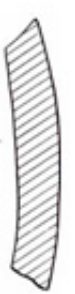

3

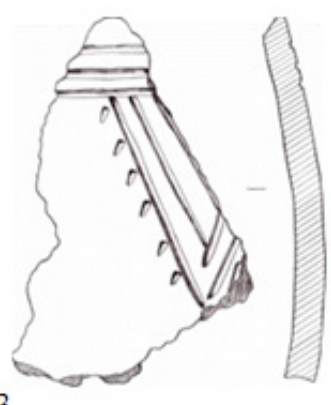

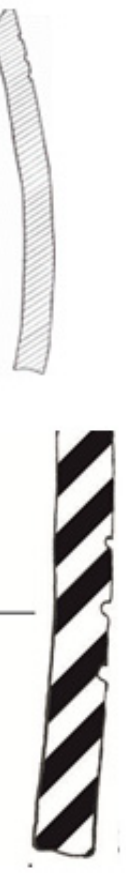

9

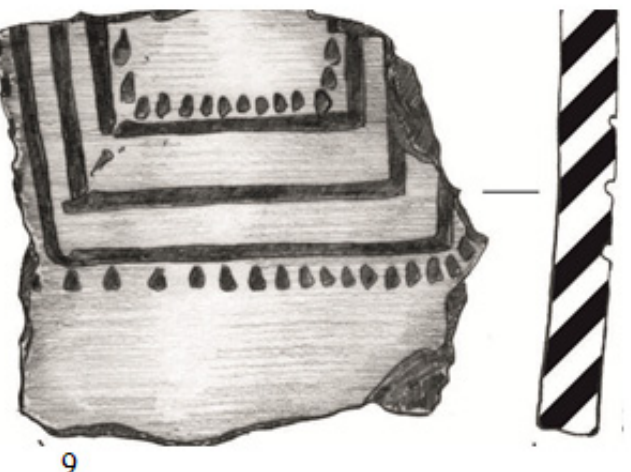

8

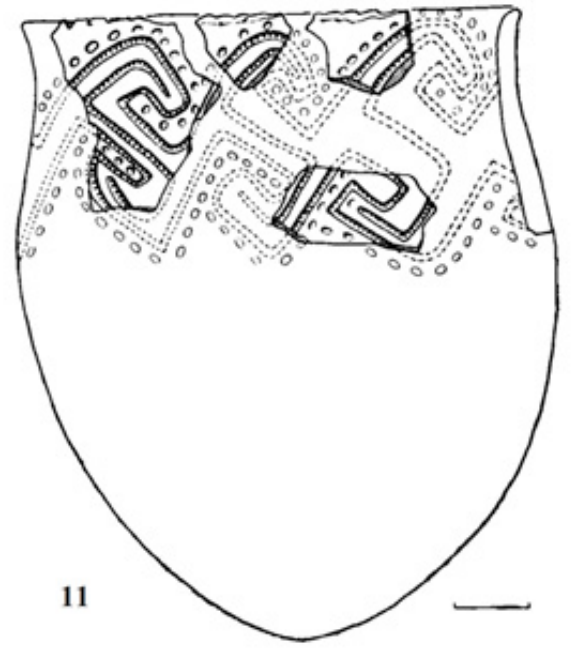

10

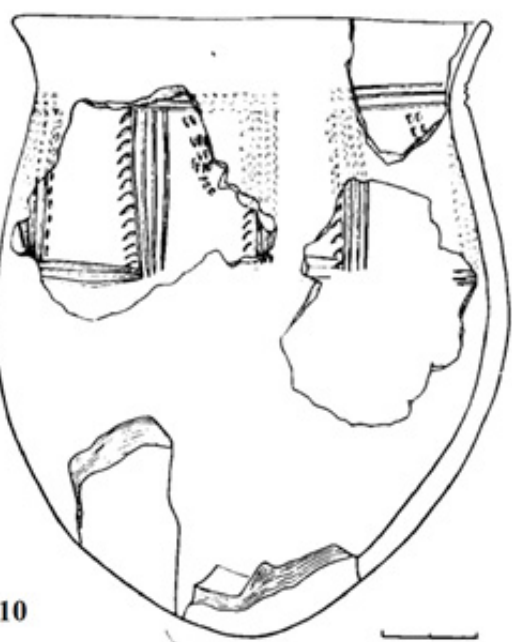

Рис.1. 1-8 керамика стоянки Каиршак III; 9-Байбек; 10, 11 - Сероглазовская керамика

\section{ABOUT THE RATIO OF MONUMENTS OF THE KAIRSHAKSKY AND TENTEKSORSKY TYPES}

(C)2014

A. Baratskov, postgraduate student of Department of Russian History and Archeology

Samara State Academy of Social Sciences and Humanities, Samara (Russia)

Annotation: Of the basis of new information and estimates material worked out carefully, the author explains the thesis that the monuments of the kairshaksky and tenteksorsky types are logical stages of one culture, confirming A.A. Vybornov assumption.

Key words: The Lower Volga Region; North Caspian; Neolithic age; kairshaksko-tenteksorsky culture; archeological pottery; flinty manufacture. 